\title{
The initiation of the students' meaning formation via the meaning essay
}

\author{
Svetlana Bezoluk ${ }^{1, *}$, Elena Azarko ${ }^{1}$, Veronika Sannikova ${ }^{1}$ and Olga Derezko ${ }^{1}$ \\ ${ }^{1}$ Don State Technical University, 1, Gagarin sq., Rostov-on-Don, 344003, Russia
}

\begin{abstract}
The author's approach to the technology of "meaning essay" is proposed as a method of initiating the meaning formation of students; the author's interpretation of the term "meaning essay" is given. The authors emphasize the importance of methods and technologies for meaning formation as effective meaning techniques used in the conditions of transformation of education during the transition to the official distance learning. Among the typical disadvantages of "distance education" are discussed the following ones: changes in the form of interaction between teacher and student, decrease of the emotional contact and loss of the emotional connection, transition from the "real" communication - to "virtual" communication via the Internet communications. An "essay" technology is considered from the position of meaning formation. Also the possibilities of a meaning essay as a meaning technique for lessons of the social and humanitarian subjects are shown. A theoretical comparative analysis of the "essays" and "compositions" is carried out. The following mechanisms of initiating the formation of students' meanings are shown: through involvement into the dialogue, actualization of personal meanings and empathy, the comprehension of socialized meanings through awareness and understanding of attitudes, contradictions, values and emotional codes. The article presents the analysis of the value orientations according to the method of M. Rokeach and the content analysis of the semantic sphere of the schoolchildren of two age groups: 12-13 and 16-17 years old. The empirical work carried out allows to form possible themes of the "meaning essays" in relation to social studies lessons for the students of the secondary schools 12-13 years old (the seventh grade).
\end{abstract}

\section{Introduction}

\subsection{Relevance}

In the context of the modern education transformation, the transition to the official distance education, the form of interaction between the teacher and the student is changing significantly. The "real" communication is being replaced by the "virtual", namely by means of the Internet communications. The lack of engagement into the dialogue, the decrease of

\footnotetext{
*Corresponding author: sveta-ya7@ya.ru
} 
the empathy and the loss of emotional connection are some of the negative consequences of "distance education".

\subsection{Problem statement}

Thereby the teachers face new challenge: the need of the development of technologies which will initiate the meaning education of students and affect the semantic sphere in the context of the distance education. The meaning didactics, as a rather young scientific and academic discipline, is a combination of didactics and psychological comprehension [1]. The purposes, objectives and learning technologies are considered in a new way in the context of this meaning didactics. The improving nowadays humanistic paradigm of education sets before the educational institutions the problem of achieving the personal results in learning first of all.

The knowledge filled with personal meanings allows the student, as a first-hand participant of the educational process, to look at the teacher's requirements from a different point. They don't just do as the teacher said, as it was with the cognitive approach to learning, but do it themselves, because they see their own meaning in it.

This is where the contradiction lies between the requirements for personal learning outcomes and the level of assimilation of knowledge in the classroom recommended by the Federal State Educational Standards and the actual teacher's cognitive requirement. The high interest in learning appears only when the dynamic meaning system of the personality function sat the personal conscious level. One of the technologies that will make possible to bring the studied information to the level of personal meaning, and most importantly, creates an opportunity to do it online, is the "meaning essay".

\section{The objective of the research}

The objective of the study is to investigate the change in the individual components of the meaning sphere (priority values, attitudes, dispositions) of the students between 12-13 and 16-17 years during the meaning essay applying.

\section{Materials and methods}

The following materials and methods are used in the article: the method "Value orientations" of M. Rokich, the author's version of "Unfinished sentences" with further content analysis, an interdisciplinary method of pedagogy and psychology - the "meaning essay" technique as an element of a formative experiment and the F-test of equality of variances as the statistical analysis method.

\section{Analysis of publications}

In this work, the authors based on the fundamental D.A. Leontiev's researches of the psychology of the meaning. The "meaning essays" in the classrooms can become an effective "meaning technique", which can change the meaning dynamics of personality because of the impact on it [2]. The teacher, as a participant in the "two-pronged process"will contribute to the acquisition of meaning by students by initiating the formation of meaning, activating cognitive interest, influencing the personal and emotional state. The meaning is "always the meaning of something" and at the same time it is always "my personal meaning" [3]. Zorina E.S. provides the classification of the "meaning techniques" and focuses on such of their particular property as - "address directly to the child, his life experience and inner world" [4]. 
The historical aspect of the genre "essay" emergence is considered in the article by I.N. Mineeva. She also reveals the types of modern essays in domestic and foreign practice, gives recommendations for the preparation, writing and evaluation of an academic essay. [5]. According to Antonova V.V. the "essay" "represents the author's existential reflection, which originates from the" inner self "to something" universal". The essay begins the retreat from the virtual (artistically) world to the real (inner) world. V. Egorova points out that the presence of a personal beginning is the main criterion of the essay [6]. The recommendations of I.N. Kretova about the possibilities of personal reflection are used in this work [7]. Some foreign studies are also devoted to the topic of the essay $[13,14]$.

Nowadays, the essay is one of the most popular forms of written work for students of the education institutions. Most often it is used by teachers of the social and humanitarian subjects (literature, history, social studies). This kind of written work allows to reveal the creative abilities of students, their hidden potential, to induce their independent reflection and expression their own thoughts. The creative people characterize the "essays" as a free "stream of consciousness", where the fulfillment of the content with meaning is much more important than the withstanding the main criteria. The term essay originates from the French word "essai"which means "trial", "sketch", in Latin we find the word "exagium" which can be translated as "weighing». In most dictionaries the essay is a small literary composition that has a free form. In the educational literature there are several "synonyms" for essays: "minicomposition", "feature article", "reasoning composition" (separating from the analyzing composition), etc.

A comparative table 1 offers the analysis of the main characteristics of the essay and composition. It also highlights the differences between the standard essay and the "meaning essay" (Table 1).

Table 1.The comparative characteristics of the composition, the essay and the meaning essay.

\begin{tabular}{|c|c|c|c|}
\hline & Composition & Essay & Meaning essay \\
\hline Size & $\begin{array}{l}\text { Recommended } \\
\text { (e.g:Graduating } \\
\text { composition contains } 350 \\
\text { words) }\end{array}$ & No limits & No limits \\
\hline Form & $\begin{array}{l}\text { Conventional (has a } \\
\text { cliché or example) }\end{array}$ & Free & Free \\
\hline Structure & $\begin{array}{l}\text { Preassigned(introduction, } \\
\text { main part, conclusion) }\end{array}$ & $\begin{array}{l}\text { There are some given } \\
\text { criteria (disclosure of } \\
\text { the meaning of the } \\
\text { quote, theoretical and } \\
\text { factual } \\
\text { argumentation) }\end{array}$ & $\begin{array}{l}\text { Can be characterized by } \\
\text { internal meaning unity }\end{array}$ \\
\hline Specificity & Can contain some & $\begin{array}{l}\text { The presence of the } \\
\text { author's manner }\end{array}$ & $\begin{array}{l}\text { Is one of the "meaning } \\
\text { tasks" that initiates the } \\
\text { development of the } \\
\text { meaning sphere }\end{array}$ \\
\hline $\begin{array}{l}\text { Presence of } \\
\text { conclusions }\end{array}$ & Obligatory & No & Not obligatory \\
\hline Content & \multicolumn{2}{|c|}{ Presenting one's thoughts on the given topic } & $\begin{array}{l}\text { The content is focused on } \\
\text { the personal values }\end{array}$ \\
\hline
\end{tabular}

It is noticeable that it is an error to call an essay some specific kind of composition. The main things in it are the author's own thoughts, based on a personal attitude to the given topic, highlighting the problem and its possible solutions and the argumentation based on his own experience. In addition, the "meaning essay" is an effective meaning technique of the internal dialogue which is capable of bringing the information to the level of personal meaning. 
The table 2 presents possible topics of the "meaning essays", which were offered to the students during the academic year as a homework and for assessing their knowledge. The section "Economics" (L.N. Bogolyubov's program "Social Studies" for the seventh grade) is the most difficult for students of the 7th grade, therefore, as an example, the topics of this particular section are proposed [8]. The topics of the meaning essays varied, since the students were asked to come up with essay topics themselves as a homework (Table 2).

From the proposed table, we see that the use of such a meaning technique as a "meaning essay" meets the basic requirements of the meaning approach, and also the teacher has the ability to vary topics [9].

Table 2. Possible topics of the meaning essays.

\begin{tabular}{|c|c|c|c|}
\hline & $\begin{array}{l}\text { Topic of the } \\
\text { lesson }\end{array}$ & $\begin{array}{l}\text { Possible topics of the } \\
\text { "meaning essays" }\end{array}$ & $\begin{array}{l}\text { Topics of the "meaning } \\
\text { essays" proposed by the } \\
\text { students }\end{array}$ \\
\hline 1. & $\begin{array}{l}\text { Economy and its } \\
\text { main participants }\end{array}$ & $\begin{array}{l}\text { Can the economy meet all the } \\
\text { needs of people? } \\
\text { "The economy changes with } \\
\text { life." (S. Vayn) }\end{array}$ & $\begin{array}{l}\text { What is the economy for? } \\
\text { What kind of consumer am I? }\end{array}$ \\
\hline 2. & The skill of worker & $\begin{array}{l}\text { Can everyone become a } \\
\text { professional in their work? } \\
\text { What kind of work do you want } \\
\text { to do in the future? }\end{array}$ & $\begin{array}{l}\text { Choice of the profession: money } \\
\text { or a benefit to the society? }\end{array}$ \\
\hline 3. & $\begin{array}{l}\text { Production: costs, } \\
\text { revenues, profits }\end{array}$ & $\begin{array}{l}\text { Is everything profitable to } \\
\text { produce? }\end{array}$ & $\begin{array}{l}\text { Would I be able to produce } \\
\text { something that does not give me } \\
\text { profit, but benefits people? }\end{array}$ \\
\hline 4. & $\begin{array}{l}\text { Types and forms } \\
\text { of business }\end{array}$ & $\begin{array}{l}\text { They say that "business is a } \\
\text { combination of war and sport," } \\
\text { but is it possible not to fight? }\end{array}$ & $\begin{array}{l}\text { What qualities do I think an } \\
\text { entrepreneur should have? }\end{array}$ \\
\hline 5. & $\begin{array}{l}\text { Exchange, trade, } \\
\text { advertising }\end{array}$ & $\begin{array}{l}\text { How do you feel about the } \\
\text { saying "You won't deceive, } \\
\text { won't you sell?" }\end{array}$ & $\begin{array}{l}\text { Are my purchases always } \\
\text { successful? }\end{array}$ \\
\hline 6. & $\begin{array}{l}\text { Money and their } \\
\text { functions }\end{array}$ & Money: good or evil & $\begin{array}{l}\text { What is the meaning of money } \\
\text { for me? }\end{array}$ \\
\hline 7. & Family economy & $\begin{array}{l}\text { Why should you plan your } \\
\text { family budget? }\end{array}$ & $\begin{array}{l}\text { What do I need to be a lean } \\
\text { owner? }\end{array}$ \\
\hline
\end{tabular}

At the same time, the essay topics are strictly recommended by the authors in most textbooks of the social and humanitarian cycle, which contradicts the main criterion of the essay - freedom [12]. This assumes that once within the scope of the theme, the student must see the meaning in the presented as an assignment topic. That's why it is recommended to offer several topics, as well as give students the opportunity to come up with topics for "meaning essays" themselves.

\section{Key results and discussion}

The empirical work was carried out in social studies lessons at a general education school in Rostov-on-Don. The sample consisted of two groups: 105 students of the $7^{\text {th }}$ grade $(12-13$ years old - 30 people) and $10^{\text {th }}$ grade (16-17 years old - 75 people): girls and boys.

The technology of the "meaning essay" was used; the topics taken as the basis were from the program of the "Social Studies" course of the 7th and 10th grades. The course program was approved by the Ministry of Education of the Russian Federation and took into the account the requirements of the Federal State Educational Standard of the Russian Federation for the development of general education programs [8]. One of the requirements for the meta- 
subject results of mastering the social science by students is the elaboration of their own attitude to certain phenomena and formulation of their own point of view. As a result, the table 2 was compiled demonstrating the essay topics offered to students in the textbook, the author's version of the meaning essay topics and the topics proposed by students during the academic year. This form of work has become especially relevant in the context of distance education. The "essay" became one of the types of homework while students independently studied the educational material (theory).

The students were tested by the method of M. Rokeach "Value orientations " of the $7^{\text {th }}$ and $10^{\text {th }}$ grades at the beginning and at the end of the academic year. The analysis of the collected data is presented in Table 3.

Table 3.The study of value orientations according to the method of M. Rokeach.

\begin{tabular}{|c|c|c|c|c|c|c|c|c|}
\hline \multirow{3}{*}{$\begin{array}{c}\text { Rating } \\
\text { of } \\
\text { values }\end{array}$} & \multicolumn{8}{|c|}{ Results } \\
\hline & \multicolumn{2}{|c|}{$\begin{array}{l}12-13 \text { years } \\
(01.09 .2019)\end{array}$} & \multicolumn{2}{|c|}{$\begin{array}{c}12-13 \text { years } \\
(31.06 .2020)\end{array}$} & \multicolumn{2}{|c|}{$\begin{array}{c}\text { 16-17 years } \\
(01.09 .2019)\end{array}$} & \multicolumn{2}{|c|}{$\begin{array}{c}\text { 16-17 years } \\
(31.06 .2020)\end{array}$} \\
\hline & values & $\%$ & values & $\%$ & values & $\%$ & values & $\%$ \\
\hline \multicolumn{9}{|c|}{ Terminal values, (boys) } \\
\hline $\begin{array}{l}1^{\text {st }} \\
\text { place }\end{array}$ & True friendship & 65 & Creation & 74 & $\begin{array}{l}\text { Comfortable } \\
\text { life }\end{array}$ & 67 & $\begin{array}{l}\text { An exciting } \\
\text { life }\end{array}$ & 62 \\
\hline $\begin{array}{l}2^{\text {nd }} \\
\text { place }\end{array}$ & $\begin{array}{l}\text { Comfortable } \\
\text { life }\end{array}$ & 49 & Wisdom & 59 & $\begin{array}{l}\text { True } \\
\text { friendship }\end{array}$ & 53 & Freedom & 47 \\
\hline $\begin{array}{l}3^{\text {rd }} \\
\text { place }\end{array}$ & Pleasure & 48 & Freedom & 47 & Pleasure & 51 & Creation & 39 \\
\hline $\begin{array}{l}4^{\text {th }} \\
\text { place }\end{array}$ & Self-respect & 41 & $\begin{array}{l}\text { The } \\
\text { happiness } \\
\text { of others }\end{array}$ & 41 & $\begin{array}{l}\text { Social } \\
\text { recognition }\end{array}$ & 37 & $\begin{array}{l}\text { The } \\
\text { happiness } \\
\text { of others }\end{array}$ & 32 \\
\hline $\begin{array}{l}5^{\text {th }} \\
\text { place }\end{array}$ & Mature love & 27 & $\begin{array}{l}\text { An exciting } \\
\text { life }\end{array}$ & 37 & Mature love & 31 & $\begin{array}{l}\text { Family } \\
\text { security }\end{array}$ & 28 \\
\hline \multicolumn{9}{|c|}{ Terminal values, (girls) } \\
\hline $\begin{array}{l}1^{\text {st }} \\
\text { place }\end{array}$ & Mature love & 73 & $\begin{array}{l}\text { An exciting } \\
\text { life }\end{array}$ & 63 & Mature love & 69 & $\begin{array}{l}\text { Family } \\
\text { security }\end{array}$ & 72 \\
\hline $\begin{array}{l}2^{\text {nd }} \\
\text { place }\end{array}$ & Self-respect & 59 & $\begin{array}{l}\text { The } \\
\text { happiness } \\
\text { of others }\end{array}$ & 59 & $\begin{array}{l}\text { Social } \\
\text { recognition }\end{array}$ & 63 & $\begin{array}{l}\text { The } \\
\text { happiness } \\
\text { of others }\end{array}$ & 68 \\
\hline $\begin{array}{l}3^{\text {rd }} \\
\text { place }\end{array}$ & Pleasure & 52 & Freedom & 53 & Pleasure & 49 & Creation & 61 \\
\hline $\begin{array}{l}4^{\text {th }} \\
\text { place }\end{array}$ & $\begin{array}{l}\text { Comfortable } \\
\text { life }\end{array}$ & 51 & Wisdom & 31 & $\begin{array}{l}\text { True } \\
\text { friendship }\end{array}$ & 47 & Freedom & 53 \\
\hline $\begin{array}{l}5^{\text {th }} \\
\text { place }\end{array}$ & True friendship & 35 & Creation & 26 & $\begin{array}{l}\text { Comfortable } \\
\text { life }\end{array}$ & 23 & $\begin{array}{l}\text { An exciting } \\
\text { life }\end{array}$ & 38 \\
\hline \multicolumn{9}{|c|}{ Instrumental values, (boys) } \\
\hline $\begin{array}{l}1^{\text {st }} \\
\text { place }\end{array}$ & Tolerance & 61 & Intellectual & 71 & Courageous & 65 & $\begin{array}{l}\text { Broad- } \\
\text { minded }\end{array}$ & 53 \\
\hline $\begin{array}{l}2^{\text {nd }} \\
\text { place }\end{array}$ & Self-controlled & 59 & Courageous & 51 & Cheerful & 57 & $\begin{array}{l}\text { Self- } \\
\text { controlled }\end{array}$ & 52 \\
\hline $\begin{array}{l}3^{\text {rd }} \\
\text { place }\end{array}$ & Courageous & 47 & $\begin{array}{l}\text { Broad- } \\
\text { minded }\end{array}$ & 42 & Loving & 44 & Intellectual & 51 \\
\hline $\begin{array}{l}4^{\text {th }} \\
\text { place }\end{array}$ & Honest & 31 & Tolerance & 39 & Honest & 39 & Responsible & 46 \\
\hline $\begin{array}{l}5^{\text {th }} \\
\text { place }\end{array}$ & Loving & 23 & Responsible & 37 & Forgiving & 21 & Forgiving & 29 \\
\hline \multicolumn{9}{|c|}{ Instrumental values, (girls) } \\
\hline $\begin{array}{l}1^{\text {st }} \\
\text { place }\end{array}$ & Loving & 77 & Responsible & 63 & Forgiving & 79 & Forgiving & 71 \\
\hline
\end{tabular}




\begin{tabular}{|l|l|l|l|l|l|l|l|l|}
\hline $\begin{array}{l}2^{\text {nd }} \\
\text { place }\end{array}$ & Honest & 69 & Forgiving & 61 & Loving & 66 & Responsible & 54 \\
\hline $\begin{array}{l}3^{\text {rd }} \\
\text { place }\end{array}$ & Courageous & 53 & $\begin{array}{l}\text { Broad- } \\
\text { minded }\end{array}$ & 58 & Honest & 61 & Intellectual & 49 \\
\hline $\begin{array}{l}4^{\text {th }} \\
\text { place }\end{array}$ & Self-controlled & 41 & Courageous & 49 & Cheerful & 43 & $\begin{array}{l}\text { Self- } \\
\text { controlled }\end{array}$ & 48 \\
\hline $\begin{array}{l}5^{\text {th }} \\
\text { place }\end{array}$ & Forgiving & 39 & Intellectual & 29 & Courageous & 35 & $\begin{array}{l}\text { Broad- } \\
\text { minded }\end{array}$ & 47 \\
\hline
\end{tabular}

The table above illustrates that the value orientations of the respondents have changed. Theratingofvalueshaschangedduringtheyear.

In the primary diagnostics conducted at the beginning of the school year, 13-year-old adolescents used to prioritize the terminal values of mature love, self-respect, pleasure, comfortable life and true friendship. The true friendship and comfortable life were on the first place among boys. However, girls tended to put the mature love, self-respect and pleasure on the leading positions. But already at the end of the year such values as creation, wisdom, freedom, the happiness of others and an exciting life moved to the first places.

At the beginning of the $10^{\text {th }}$ grade girls and boys, also had such values as comfortable life, true friendship, pleasure, social recognition and mature love on the first places. At the end of the year final test shows that an exciting life, freedom, creation, the happiness of others, and family security became the main values on the lists of majority. In both cases at the beginning of the year, predominating values were meeting the needs of the adolescents themselves, creating comfortable conditions for them, which is typical to their environment and age.

The values chosen at the end of the year demonstrate that the vector has turned outwards, towards creation, an exciting life, the happiness of other people. The instrumental values chosen by 13-year-olds were being loving, courageous, tolerant, honest, and self-controlled. Moreover, among girls the value of "being loving" was the most important. Among the 13year-old and 16-year-old boys one of the most important values was being forgiving.

We have to admit that the emphasis also shifted in instrumental values, the students finally gave more preference to cognitive values was given, e.g. being intellectual, broad-minded and responsible for their actions. Thus, we can conclude that the use of such techniques as the "meaning essay" in the work of teachers leads to the development of personality, understanding of moral norms and values, changes in the worldview, self-determination, and the formation of a world picture of students.

The diagnostics of personal attitudes was carried out using the methodology "Incomplete sentences", were highlighted some typical answers that allow the teacher to determine the emotional state of students, their feelings, difficulties they face. The analysis is presented in Table 4. The students were proposed to complete five sentences: 1) An essay is...; 2) This form of assessment in the lesson for me ...; 3) When I write an essay, I think about ...; 4) While working on the essay, I acquired ...; 5) Essays in the class made me think about...

The table 4 demonstrates that, describing the essay in general, as a form of work, adolescents mostly perceive it as an opportunity to express their opinion on paper. About $81 \%$ of students $12-13$ years old (50\% girls and 30\% boys $12-13$ years old) expressed such opinion. However, among $16-17$ year old adolescents only $27 \%$ (11\% - boys and $16 \%$ girls) did so. The essay is perceived as a short story by $50 \%$ of $12-13$ year old boys and girls and $18 \%$ of $16-17$ year old students. Girls of 12-13 years old made up 27\%, 23\% were $12-13$ years old boys, $10 \%$ were $16-17$ years old boys and $8 \%$ were $16-17$ years girls. Those who perceive the essay as the composition made up about $32 \%$ of respondents $12-13$ years old and $18 \%$ of $16-17$ years old, students. $23 \%$ of them were $12-13$ years old men, $8 \% 12-13$ years old girls, $10 \% 16-17$ years old and 8\% 16-17 years old girls. 
Table 4. Analysis of the methodology "Incomplete sentences".

\begin{tabular}{|c|c|c|c|c|c|c|c|c|c|}
\hline \multirow{2}{*}{$\begin{array}{l}\text { Unfinished sentences } / / \\
\text { typical responses }\end{array}$} & \multicolumn{4}{|c|}{$\begin{array}{c}\text { Students of } \\
12-13 \text { years old ( } 30 \\
\text { people) }\end{array}$} & \multicolumn{4}{|c|}{$\begin{array}{c}\text { Students of } \\
16-17 \text { years mold ( } 75 \\
\text { people) }\end{array}$} & \multirow[t]{2}{*}{ Fandp $=$} \\
\hline & $\begin{array}{c}\mathrm{N}, \\
\text { peop. }\end{array}$ & $\begin{array}{l}\mathbf{N}, \\
\%\end{array}$ & $\begin{array}{l}\mathrm{U}, \\
\%\end{array}$ & $\begin{array}{l}\mathrm{D}, \\
\%\end{array}$ & $\begin{array}{c}\mathrm{N}, \\
\text { peop. }\end{array}$ & $\begin{array}{l}\mathbf{N}, \\
\%\end{array}$ & $\begin{array}{l}\mathrm{U}, \\
\%\end{array}$ & $\begin{array}{l}\mathrm{D}, \\
\%\end{array}$ & \\
\hline \multicolumn{10}{|l|}{ An essay is... } \\
\hline $\begin{array}{l}\text {-an opportunity to express } \\
\text { your own opinion on } \\
\text { paper ** }\end{array}$ & 24 & 80 & 30 & 50 & 21 & 28 & 11 & 17 & $\mathrm{~F}=5.09 \mathrm{p}=0,00$ \\
\hline -short story with meaning & 15 & 50 & 23 & 27 & 13 & 17 & 10 & 7 & $\mathrm{~F}=3.296 \mathrm{p}=0,0005$ \\
\hline $\begin{array}{l}\text {-almost the same as } \\
\text { composition, but easier. } \\
\text { You don't have to stick to } \\
\text { form and count words * }\end{array}$ & 10 & 33 & 23 & 10 & 13 & 17 & 10 & 7 & $\mathrm{~F}=1.723 \mathrm{p}=0,0425$ \\
\hline \multicolumn{10}{|c|}{ This form of assessment in the lesson for me... } \\
\hline $\begin{array}{l}\text {-like it, it's easier than } \\
\text { learning a paragraph ** }\end{array}$ & 25 & 83 & 30 & 53 & 26 & 35 & 18 & 17 & $\mathrm{~F}=4.821 \mathrm{p}=0,0$ \\
\hline $\begin{array}{l}\text {-easier than writing the } \\
\text { composition** }\end{array}$ & 12 & 40 & 20 & 20 & 13 & 17 & 8 & 9 & $\begin{array}{l}F=2.364 \\
p=0,009\end{array}$ \\
\hline $\begin{array}{l}\text {-allows you to get a good } \\
\text { mark** }\end{array}$ & 12 & 40 & 20 & 20 & 8 & 11 & 6 & 5 & $\mathrm{~F}=3.259 \mathrm{p}=0,0006$ \\
\hline \multicolumn{10}{|c|}{ When I write an essay, I think about... } \\
\hline $\begin{array}{l}\text {-about my } \\
\text { experience and } \\
\text { apply it } * *\end{array}$ & 18 & 60 & 26 & 34 & 24 & 32 & 11 & 21 & $\mathrm{~F}=2.637 \mathrm{p}=0,0042$ \\
\hline $\begin{array}{l}\text {-about how to correctly } \\
\text { formulate my thoughts on } \\
\text { paper ** }\end{array}$ & 22 & 73 & 33 & 39 & 16 & 21 & 9 & 12 & $\mathrm{~F}=5.074 \mathrm{p}=0,00$ \\
\hline $\begin{array}{l}\text {-about getting a good } \\
\text { mark** }\end{array}$ & 11 & 37 & 20 & 17 & 7 & 9 & 4 & 5 & $\mathrm{~F}=3.174 \mathrm{p}=0,008$ \\
\hline \multicolumn{10}{|c|}{$\begin{array}{l}\text { While working on the essay, I acquired } \\
\ldots\end{array}$} \\
\hline $\begin{array}{l}\text {-an opportunity to } \\
\text { understand the subject } \\
\text { better** }\end{array}$ & 19 & 63 & 33 & 30 & 19 & 28 & 13 & 15 & $\mathrm{~F}=3.638 \mathrm{p}=0,0001$ \\
\hline $\begin{array}{l}\text {-be creative in answering a } \\
\text { question } * *\end{array}$ & 18 & 60 & 27 & 33 & 18 & 24 & 7 & 17 & $\mathrm{~F}=3.464 \mathrm{p}=0,003$ \\
\hline $\begin{array}{l}\text {-began to write essays } \\
\text { better * }\end{array}$ & 11 & 37 & 13 & 24 & 12 & 16 & 6 & 10 & $\mathrm{~F}=2.212 \mathrm{p}=0,0135$ \\
\hline \multicolumn{10}{|c|}{ The essays in the class made me think about ... } \\
\hline $\begin{array}{l}\text {-about the meaning of } \\
\text { life** }\end{array}$ & 19 & 63 & 27 & 36 & 22 & 29 & 13 & 16 & $\mathrm{~F}=3.222 \mathrm{p}=0,0006$ \\
\hline -the benefit that I bring $* *$ & 18 & 60 & 27 & 33 & 18 & 24 & 13 & 11 & $\mathrm{~F}=3.464 \mathrm{p}=0,03$ \\
\hline -personal, hidden * & 9 & 30 & 10 & 20 & 9 & 12 & 5 & 7 & $\mathrm{~F}=2.091 \mathrm{p}=0,0182$ \\
\hline
\end{tabular}

Note: marked ${ }^{*}$ - significant differences at $\rho=0.05$ both for $\mathrm{N} 1=30$ and $\mathrm{N} 2=75$; ** - significant differences at $\rho=0.01$ for $\mathrm{N} 1=30$ and $\mathrm{N} 2=75$.

In the perception of the essay as a form of assessment in the lesson, the following results are observed: the answer "I like it, it is easier than learning a paragraph" chose $83 \%$ of students $12-13$ years old (30\%boys and 53\% girls) and 35\% of $16-17$ year old adolescents ( $17 \%$ girls and $18 \%$ boys). About $40 \%$ of $12-13$ years old students ( $20 \%$ girls and $20 \%$ boys) and $17 \%$ of $16-17$ years old ones ( $9 \%$ girls and $8 \%$ boys) believe that writing an essay is easier than writing a composition. The option that the essay allows you to get a good mark 
was indicated by $40 \%$ of adolescents of $12-13$ years old (20\% girls and $20 \%$ boys), and $11 \%$ of $16-17$ years old ( $6 \%$ boys and $5 \%$ girls).

In the process of writing the essay, $60 \%$ of $12-13$ years old respondents thought about their personal experience and possibility of applying it. This option was the most popular among girls (34\%) and on the second place among boys (26\%). Among the adolescents of 16-17 years old, this option was chosen by $32 \%$ ( $21 \%$ of them were girls and $11 \%$ boys). About $73 \%$ of students 12-13 years old thought about how to correctly formulate their thoughts on paper, $39 \%$ of them were girls and 34\% were 12-13 years old boys. Among the 16-17 years old students, this option was chosen by $21 \%$ ( $12 \%$ were girls and $9 \%$ were boys). The focus on getting a good mark was observed among $37 \%$ of $12-13$ year old students $(20 \%$ were boys and $17 \%$ were girls), $16-17$ years old respondents had a much lower overall percentage in this column, only $9 \%$ (4\% girls and 5\% boys).

When the students were asked what they acquired while working on the essay the opportunity to understand the subject deeper chose $63 \%$ of respondents $12-13$ years old (30\% girls, $33 \%$ boys) and $28 \%$ of $16-17$ year old students (13\% boys and $15 \%$ girls). About $60 \%$ of $12-13$ years old adolescents (33\% of girls and $27 \%$ of boys) and $24 \%$ of $16-17$ years old ones ( $7 \%$ boys and $17 \%$ girls) decided to be creative in answering the question. In addition, $37 \%$ of $12-13$ years old students (24\% girls and $13 \%$ boys) and $16 \%$ of $16-17$ years old ones ( $6 \%$ boys and $10 \%$ girls) believed that they began to write the essays better.

As a result, $63 \%$ of $12-13$ years old students thought about the meaning of life (36\% girls and $27 \%$ boys), among the $16-17$ years old respondents, $29 \%$ chose this option ( $16 \%$ girls and $13 \%$ boys). Also $60 \%$ of $12-13$ years old respondents (33\% girls and $27 \%$ boys) and $24 \%$ of adolescents $16-17$ years old (11\% girls, 13\% boys) started thinking about the benefits they bring to the others. About $30 \%$ of students $12-13$ years old (20\% girls and $10 \%$ boys) and $12 \%$ of $16-17$ years old ones ( $5 \%$ boys and $7 \%$ girls) wrote about personal, hidden things.

During the analysis of the tables 3 and 4 some coincidences were observed. For instance, the students talk about such values as creation ("to be creative in answering a question"), wisdom ("the ability to understand the subject deeper"), the happiness of others ("about the benefit that I bring"), an exciting life ("apply personal experience ").It should be noted that the outward orientations prevail in the respondents' answers (see Table 3). This fact indirectly confirms the idea that the meaning essay as a form of work leads to the development of personality, understanding of oneself. It also improves an understanding of moral norms and values, changes the worldview, an attitude to the world around them, self-determination and also forms students' pictures of the world.

Commenting on the obtained results, we see that the percentage ratio of choices among adolescents 12-13 years old and among adolescents 16-17 years old is strikingly different. This difference can be explained by different number of participants. In total in the study took part 105 people, 30 of them were adolescents of 12-13 years old and 75 boys and girls of 1617 years old.

The dynamics in the meaning sphere were also observed. They were associated with a change in motives from external to internal, the transition from the unconscious to the conscious position ("It's easier than writing a composition", "You can approach creatively to the answer to a question"), effectiveness ("I like it, it's easier than learning a paragraph", "It allows you to get a good grade"), possible goals ("It was about the meaning of life", "The benefit that I bring"), one's attitude to life and its manageability ("About the meaning of life "," About the personal, hidden "," When I write an essay, I think about my personal experience and try to apply it ").

According to the obtained results and relying on a meaning-centered approach to education, the "meaning essay" or the "dialogue with oneself" can become an effective meaning technique capable of bringing the information to a personal level, because "the meaning possibilities are most noticeably manifesting in the dialogue" [3]. The dialogue is a 
way of self-expression, self-realization, disclosure of the inner abilities of students. As a result of the "dialogue with oneself", the child's "self" enters into the dialogue with itself at the level of internal individual consciousness. Giving the topic of an "essay" in a non-standard meaning form, the teacher touches on the "deep strings" of the child, "in a pedagogically controlled way" affects the meaning sphere and thereby contributes to its development. A meaning essay can become one of the "meaning tasks" that can "begin the interest" and become "a trigger mechanism of meaning formation" [10].

\section{Recommendations}

The formulation of several recommendations and proposals became possible based on the empirical work carried out:

- the topics of the "meaning essays" (from the Table 2) can be recommended for social studies lessons for the students of general education schools 13-14 years old ( $7^{\text {th }}$ grade);

-the methods of empirical research (test "Value orientations" by M. Rokeach and the author's version of "Unfinished sentences") can be recommended for research tasks to identify the level of meaning development of students during the implementation of meaning formation in the educational process.

\section{Conclusions and perspectives}

Summing up, several conclusions can be drawn:

1. The "meaning essay" as a technique of meaning formation can become an effective meaning technique, capable of bringing the information to a personal level.

2. The meaning essay may be one of the "meaning tasks" that are able to "begin the interest" and "trigger the meaning formation" [11].

3. Students are characterized by the following values and their rating from the first to the fifth position:

- for 12-13 years old, terminal values are predominant - an exciting life, creation, happiness of others, freedom, wisdom; the predominant instrumental values are intellect, tolerance, broad-mindedness, responsibility, courage;

- for 16-17 years old, terminal values are predominant - the happiness of others, freedom, an exciting life, creation, happy family security; the predominant instrumental values are responsibility, broad-mindedness, intellect, tolerance, self-control. The change in the priority of the values of 16-17 year old boys and girls compared to 12-13 year old teenagers can be observed.

4. When using the "meaning essay" following changes can be observed:

-development of reflexive skills of adolescents, such as the ability to self-analyze their experience, actions, occurring situations. It also improves the ability to draw conclusions ("When I write an essay, I think about my personal experience and try to apply it");

- Reduction of the stress from assessment in the lesson. Presenting one's thoughts on paper has a therapeutic effect ("It's easier than writing an essay," "It allows you to get a good grade," "You don't have to adhere to the form and count words);

-development of creative and cognitive abilities ("You have to be creative in answering the question", "I improved my writing skills", "It was about correct formulation of thoughts on paper");

-dynamics in the meaning sphere. The transition from the unconscious to the conscious takes place while the motives change from external to internal, ("It's easier than writing an essay", "We have to apply a creative approach to answer the question"). In addition it increases the effectiveness ("I like it, it's easier than learning paragraph", "It allows you to 
get a good mark"), has several possible goals ("About the meaning of life", "The benefit that I bring") and changes attitude to life and its controllability ("About the meaning of life","About personal, hidden","When I write an essay, I think about my personal experience and try to apply it ").

5. The essay ceased to have a formal meaning, it became more emotional and shifted for the student to a personal, deep level ("about the meaning of life", "about the benefits that I bring," "about personal").

The research we have conducted allows us to affirm that this method can be used by a wide audience of teachers as an effective, informative and easy to use.

\section{References}

1. I.V. Abakumova, E.A. Dzyuba, North-Caucasian psychological bulletin 4, 46-52 (2009) https://cyberleninka.ru/article/n/smyslotehniki-v-uchebnom-protsesse

2. D.A. Leontiev, The psychology of meaning: nature, structure and dynamics of meaning reality (Meaning, M., 2019)

3. I.V. Abakumova, Meanin didactics (Credo, M., 2008)

4. E.S. Zorina, I.S. Dyshluyk, Effective meaning techniques in the practice of the educational process (Feniks, Rostov-on-Don, 2016)

5. I.N. Mineeva, Philological class 2, 7-13 https://cyberleninka.ru/article/n/akademicheskoe-esse-teoriya-i-praktika-zhanra

6. N.V. Egorova, Integration of education 3, 120-123 (2011) https://cyberleninka.ru/article/n/esse-i-sovershenstvovanie-gumanitarnogo-potenpialalichnosti

7. I.N. Kretova, Paradigm 3, 112-116 (2019) https://cyberleninka.ru/article/n/refleksiyalichnostnyh-dostizheniy-obuchayuschihsya-kak-regulyator-razvitiya-lichnosti.

8. L.N. Bogolyubov, N.I. Gorodetskaya, L.F. Ivanova, Social Studies. Work programs. The subject line of textbooks (Education, M., 2014)

9. I.V. Abakumova, A.M. Kukulyar, V.T. Fomenko, Russian psychological journal 11(3), 24-32 (2014) DOI: https://doi.org/10.21702/rpj.2014.3.2

10. I.V. Abakumova, V.T. Fomenko, Credo 3, 38-53 (2014)

11. N.Yu. Zilberbrandt, Bulletin of the Cherepovets State University 4, 106-109 (2013) https://cyberleninka.ru/article/n/didakticheskaya-suschnost-smyslovyh-zadach.

12. K. Rogers, Jr. Freiberg, Freedom to learn (Meaning, M., 2019)

13. P. Standish, Sun Inn Yun, J. Albright, Education Sciences 7(1), 31 (2017) https://doi.org/10.3390/educsci7010031

14. M.A. Mohsen, M. Qassem, J Psycholinguist Res 49, 435-451 (2020) https://doi.org/10.1007/s10936-020-09693-9 